\title{
Updating of language training content in Kazakhstan: implementation of new linguodidactic approaches
}

\author{
Guzaliya Zh. Fahrutdinova - Kulzhanat N. Bulatbayeva - Olga I. \\ Kondratova - Svetlana N. Fedorova - Olga A. Petukhova
}

DOI: 10.18355/XL.2018.11.02.19

\begin{abstract}
The need to improve the content of education disciplines at secondary and higher educational institutions and to create more favorable methodological conditions for curricula implementation in Kazakhstan have been gaining importance in recent years. Analyses of practical activity specified that the Kazakh, Russian and foreign languages in Kazakhstan should be primarily studied as real and full-fledged means of communication at the level of native speakers. Teaching the Kazakh, Russian and foreign languages should develop learners' communicative skills necessary for the person as a member of Kazakhstani society and global community as well. Insufficient communicative character of language subjects impedes the achievement of the state goal to develop multiculturalism in Kazakhstan. Therefore, it is crucial to distribute expected results in mastering languages at different stages of learning and to consider productive training technologies aimed to implement the objectives. The research goal of the paper is to elaborate a level model of language training and appropriate organizational conditions to master several languages simultaneously. Research results: The paper provides a level-by-level description of language training levels at school and university to guideline the development of state standards for secondary and vocational education as well as corresponding curricula and textbooks; results of research accomplishment are realized in textbooks on language subjects for high school and first- and second- years of higher education; methodological recommendations on language subjects content improvement in education institutions have been developed.
\end{abstract}

Key words: content of linguistic disciplines, thematic basis, unified speech-thematic basis, educational dialogues and monologues, functional-communicative and cognitive-communicative technologies, criteria of assessment

\section{Introduction}

One of the most important tasks for modern education system in Kazakhstan is the introduction of multilingualism into the content of education; first of all, it implies active development of three languages: the Kazakh language as the state language, the Russian language as the language of interethnic communication, and English is the language of successful integration into the global economy. In accordance with this program objectives, all citizens of Kazakhstan should master the Kazakh language, 95\% of them should know the Russian language and $25 \%$ of them should master English by 2020. On April 12, 2017, the President published the article about the urgent need to develop multilingualism of the nation in Kazakhstan. Due to declared tasks, strenuous processes of transition to trilingual education in some educational institutions have been launched; academic disciplines are taught in Kazakh, Russian and English (optional) or in Kazakh and English, or Russian and English in their integration. But the full transition to multilingual education requires a lot of effort and time. In this regard, educational institutions need the qualified assistance of scientists in the field of linguistics and pedagogy.

The studied issue was chosen in view of the need a) to solve the problem of transition to students' trilingual education in Kazakhstan; b) to implement consistency and

XLinguae, Volume 11, Issue 2, April 2018, ISSN 1337-8384, eISSN 2453-711X 
continuity of foreign language training; c) to introduce a language system on a cognitive-semantic basis to serve human's thinking activity; d) to provide methodological assistance to those specialists of non-linguistic subjects who do not have special skills in linguistic processing of educational material as the foundation of foreign communication. Thus, the key task of our research is to update the content of students' language training to develop their foreign language communicative competence.

Scientific considerations on the theory of linguistic personality proposed by Yu.N. Karaulov (2010), communicative grammar compiled by G.A. Zolotova, N.K. Anipenko and M.Yu. Sidorova (2004), communicative methods of foreign language training specified by E.I. Passov (1989), didactic fundamentals of continuity in polylingual education on the basis of a level model of languages training in the system of 'school - university' submitted by K.N. Bulatbayeva (2015), N. Li, K.V. Pyrkova, T.V. Ryabova (2017), criteria of linguistic, speech and communicative competences assessment of language training at schools and universities worked out by K.N. Bulatbayeva et al. (2014), S. Wang et al. (2018) make the foundation of this work.

To solve the objective of the paper, let us place the learner with his/her demands in communication (anthropocentric approach in linguistics and linguodidactics) into the center of multilingual personality formation model when it comes to the content selection.

The second circle from the lingual personality is represented by spheres of language functioning in its communicative activity (there are three of them in Kazakhstan context): the sphere of informal communication in which the Kazakh or Russian language is used (additionally, it can be another national language - Uighur, Uzbek, German, Tajik, Ukrainian, Belarus, etc.); the sphere of semi-official communication in public places (the Kazakh language as the state one, the Russian language as the official language); the sphere of professional communication (the professional Kazakh language as the state language, the professional Russian language as the official language, a foreign language as a language of international co-operation in the sphere of production).

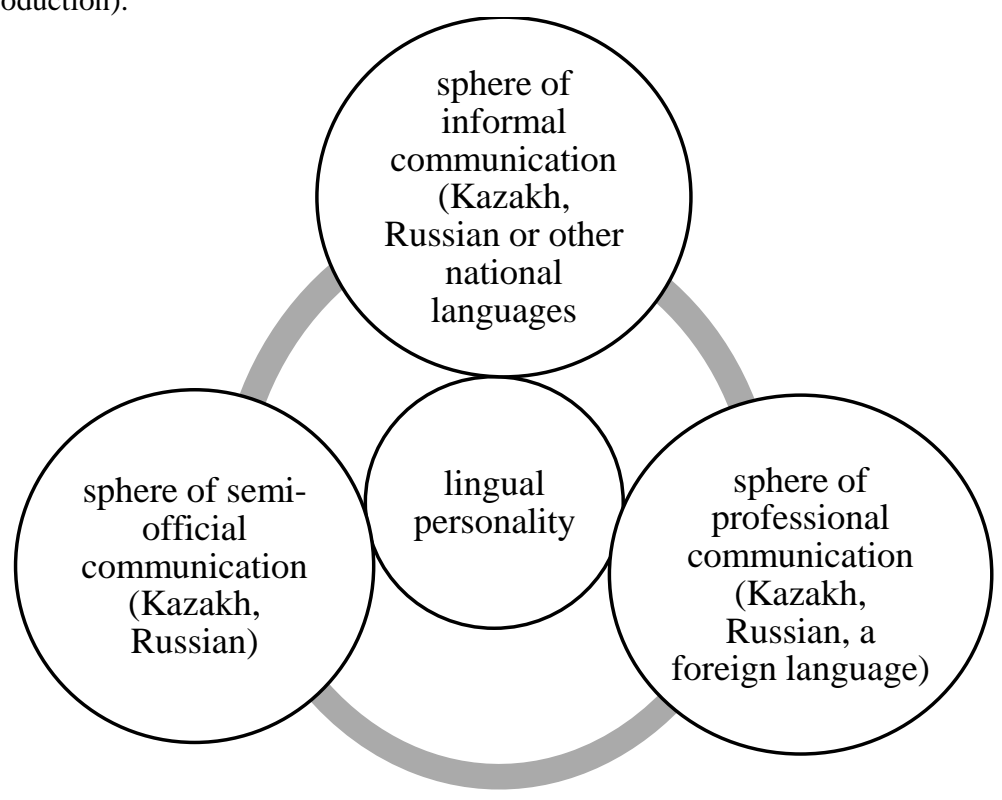

Figure 1: Extra-linguistic aspects of content selection for language training 
The third circle should determine the content of training process due to communication needs in the above mentioned spheres. On the basis of the first two spheres, the content of language training is defined adequately (thematic, lexical and grammatical minimum); it is reflected in today's operating textbooks for institutions of general secondary, secondary vocational and higher professional education. Although, it should be noted that in order to improve the efficiency of mastering nonnative languages, the issue of a unified approach to the content selection of the second and third languages and parallel training in a unified content has not been addressed. The theme of our research concerns the third sphere - the sphere of professional communication, as university students of various specialties must be ready for future multilingual professional communication.

Analyses of operating programs and the state of foreign language training (this will be discussed in detail in other paragraphs of our research) showed that the current content of operating programs and textbooks is not determined by the selection of lexical, phraseological and grammatical material on scientific bases. As for didactic material, it is a set of random texts concerning one or another specialty. Though, the process of multilingual personality formation must necessarily be based on methodological principles in the fields of psycholinguistics, theory of speech activity, cultural linguistics and intercultural communication, communicative, pragmatic and cognitive linguistics. Consequently, first and foremost, the third sphere - the sphere of professional communication - should be structured regardless of the language. For example, general medicine (first phase) is followed by parallel branching in narrow specializations (pediatrics, surgery, internal medicine, etc.). Such extra-linguistic cognitive structure will be the basis for the targeted selection of lexical, phraseological and grammatical material and represent the third circle from lingual personality. The fourth circle is determined by potential speech tasks (speech intentions) in the framework of general and narrowly specialized professional activity. Only the fifth circle should reflect the minimum of lexical, phraseological and grammatical material necessary for professional communication of the future specialist, and should be selected on the basis of classified speech intentions. 


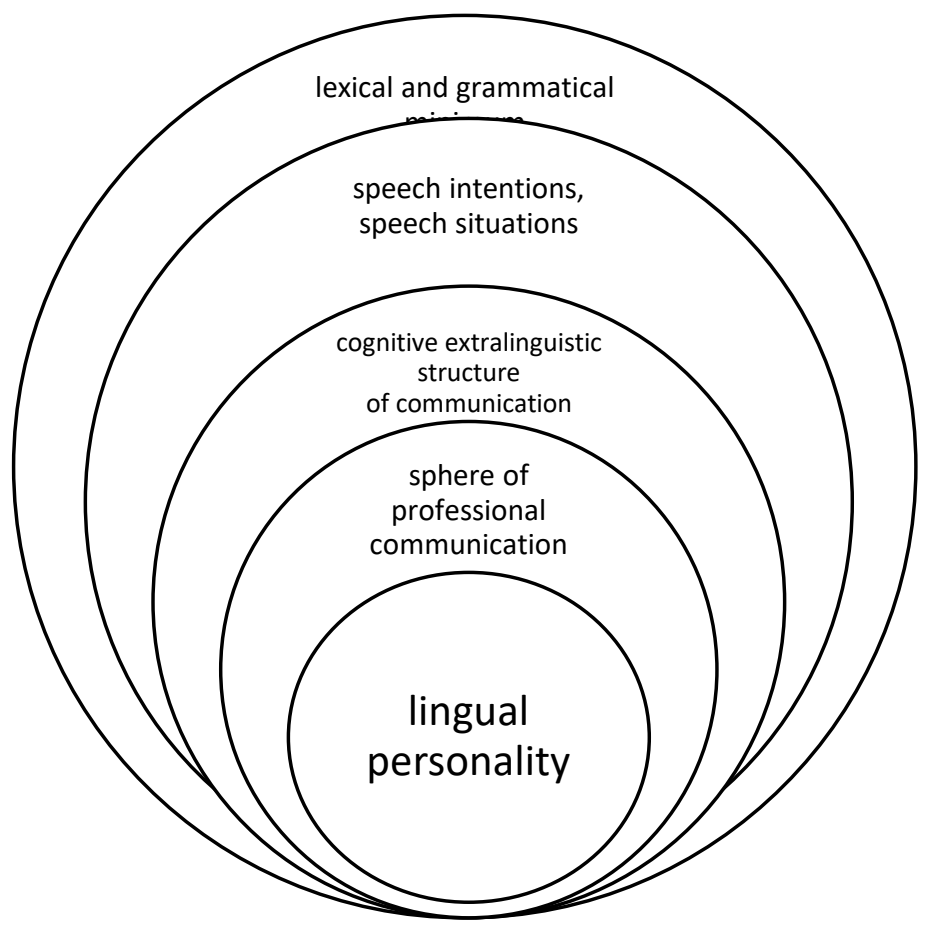

Figure 2: The mechanism of lexical and grammatical material selection for multilingual professional activity

\section{Literature Review}

In the context of cognitive-communicative approach to teaching multilingualism, new units of training are used, e.g. functional-semantic fields, lexical-semantic fields, structural- content types of dialogues and structural- content types of monologues which have become possible for application due to modern discoveries of communicative linguistics. Recently, in linguistics, the interest has been increased in studying systemic relations in language at all its levels, in particular, in vocabulary. Ideography as a relatively new direction in linguistics is developing rapidly and is considered to be a promising science. Ideographic description of vocabulary is systematization of vocabulary on a thematic principle, onomasiologically (from meaning to form). A lexical-semantic system represents a hierarchy of semantic fields reflected in the ideographic dictionary by P.M. Roget (1978). The theory of creating an ideographic dictionary-thesaurus was included in "General and Russian Ideography" by Yu. N. Karaulov (1976). Communicative grammar by G.A. Zolotova, N.K. Anipenko and M.Yu. Sidorova (2004) makes the theoretical base of our research: the system of smallest syntax units - syntaxemes allowed us to identify semantic types of elementary utterances as new effective units of grammatical material selection; we used communicative speech registers (reproductive, motivational, generative, informative, reactive), described by G.A. Zolotova, N.K. Anipenko and M.Yu. Sidorova (2004), as functional linguistic units to train to express the author's position in students' productive texts. (Bulatbayeva et al., 2015). E.I. Passov (1989) in his work "Communicative methods of teaching foreign-language 
communication" presented the strategy and tactical steps to distribute educational language material at stages of lexical and grammar skills formation and dialogue and monologue speech development. Application of a functional-communicative technology for teaching the Russian language in Kazakh school described in the work of K.A. Bulatbayeva (2005) is believed to be an effective way to implement updated content of language teaching. The system of stable communicative formulae specified by N.I. Formanovskaya (1989) plays an important role in updating the content of language education. Ethno-cultural factors of native speakers of the language studied and students themselves considered by G.Zh. Fahrutdinova (2016) serve as pedagogical bases for updating the content of education as well.

\section{Research Methodology \\ 3.1. Materials and methods}

To identify the level of language proficiency, reasons of different training levels of three languages at school and university, it was important to monitor professional competence of teachers or university professors and to make content analysis of existing curricula. The main research method was modeling of the continuous process of teaching a foreign language represented as the distribution of main speech and communicative competencies by stages of training. These competences were used to select program material on extra-linguistic basis in the context where the fundamental factor was to consider a potential demand for students' communication at a certain stage of life. The elaborated model was tested in the educational process at school and university. The experiment included three phases: stating, training and control the results of which are presented.

\subsection{Stages of research}

The investigation of the issue was conducted in three stages:

In the first stage, tasks of education system in the development of multilingualism, the state of language training at schools and universities through the learning process observation were analyzed; the content of curricula and textbooks was examined. According to "Common European Framework of Reference: Learning, Teaching, Assessment" (Common, 1996), the expected results of teaching second and third languages at schools and universities were identified.

In the second stage, a unified content (a unified thematic basis) of such subjects as "Kazakh language" (L2), "Russian language" (L2), "English language" (L3) was specified to meet the requirements of the state task of trilingual education development, a decrease of students' training load and a communicative orientation of language subjects. The textbooks with 10 thematic modules for the second and third languages were developed.

In the third stage, experimental work was completed, theoretical and practical conclusions were clarified, and obtained results were summarized and systematized.

\section{Results and Discussions \\ 4.1. Structure and Content of the Model}

The model of consistent and continuous language education is based on main speech and communication competencies of students in studied languages which will have to be expected results. It gives ground to organize the process of language training on the basis of a unified thematic minimum, and to use unified assessment criteria as well. This model also focuses on a unified approach to qualification advancement of teachers in all linguistic subjects at integrated courses aimed to arrange teachers' interrelated work. The model allows the authors to develop textbooks according to the unified concept and to avoid the application of the same material both at school and university. 
Table 1: The model of content distribution according to the level of foreign language proficiency at school and university

\begin{tabular}{|c|c|c|}
\hline 11- year school & 12-year school & Expected results \\
\hline \multicolumn{3}{|l|}{ Primary school } \\
\hline $\begin{array}{l}1-4 \text { grades } \\
\text { (primary school) } \\
\text { A1 - A2 }\end{array}$ & $\begin{array}{l}\text { 1-5 grades (primary } \\
\text { school) - A1 - A2 } \\
(2015-2020)\end{array}$ & \multirow{2}{*}{$\begin{array}{l}\text { Elementary level A1Can understand } \\
\text { and use in speech familiar phrases } \\
\text { and collocations, necessary for } \\
\text { fulfilling specific tasks. Can } \\
\text { introduce oneself/somebody, ask and } \\
\text { answer questions about place of } \\
\text { living, friends, and family. Can take } \\
\text { part in simple conversations if a } \\
\text { partner speaks slowly and distinctly } \\
\text { and is ready to help. }\end{array}$} \\
\hline $\begin{array}{l}\text { A0 - pre-school } \\
\text { education } \\
\text { A1 }-1 \text { grade } \\
\text { A1.1- } 2 \text { grade } \\
\text { A1.2-3 grade } \\
\text { A2 }-4 \text { grade }\end{array}$ & $\begin{array}{l}\text { A0 - preschool } \\
\text { education } \\
\text { A1 }-1 \text { grade } \\
\text { A1.1- } 2 \text { grade } \\
\text { A1.2 }-3 \text { grade } \\
\text { A2 }-4 \text { grade } \\
\text { A2.1- } 5 \text { grade }\end{array}$ & \\
\hline 11- year school & \begin{tabular}{l|l|}
12 -year school \\
\end{tabular} & Expected outputs \\
\hline \multicolumn{3}{|c|}{ Secondary school } \\
\hline $\begin{array}{l}5-9 \text { grades } \\
\text { (secondary } \\
\text { school) - A2 - } \\
\text { B1; }\end{array}$ & $\begin{array}{l}\text { 6-10 grades (secondary } \\
\text { school) - A2 - B1 (2020- } \\
\text { 2024); }\end{array}$ & \multirow{2}{*}{$\begin{array}{l}\text { Elementary level A2 } \\
\text { Can understand separate } \\
\text { sentences and frequently used } \\
\text { collocations, connected with } \\
\text { basic spheres of life (for } \\
\text { instance, information about } \\
\text { yourself, members of a family, } \\
\text { job, purchasing etc.) Can fulfill } \\
\text { tasks connected with information } \\
\text { exchange on familiar topics. Can } \\
\text { tell about themselves, family, } \\
\text { daily routines using simple } \\
\text { sentences. }\end{array}$} \\
\hline $\begin{array}{l}\text { A2.1 -5 grade } \\
\text { A2.1.1-6 } \\
\text { grade } \\
\text { A2.1.2-7 } \\
\text { grade } \\
\text { A2.2 }-8 \text { grade } \\
\text { A2+ - } 9 \text { grade }\end{array}$ & $\begin{array}{l}\text { A2.1.1 - } 6 \text { grade } \\
\text { A2.1.2 - } 7 \text { grade } \\
\text { A2.2 }-8 \text { grade } \\
\text { A2+ - } 9 \text { grade } \\
\text { B1.1-10 grade }\end{array}$ & \\
\hline 11- year school & 12-year school & Expected outputs \\
\hline \multicolumn{3}{|c|}{ High school } \\
\hline $\begin{array}{l}\text { 10-11 grades } \\
\text { (high school) }- \\
\mathrm{B} 2\end{array}$ & $\begin{array}{l}\text { 11-12 grades (high school } \\
\text { B2 - C1 (2025-2027) }\end{array}$ & \multirow{2}{*}{$\begin{array}{l}\text { Independent user B2 } \\
\text { Can understand general meaning } \\
\text { of complex texts on abstract and } \\
\text { specific topics, including sector- } \\
\text { specific texts. Can speak fluently } \\
\text { and spontaneously enough in } \\
\text { order to communicate with } \\
\text { native speakers without } \\
\text { difficulties. Can make distinct, } \\
\text { detailed messages on different } \\
\text { topics, on basic topics and } \\
\text { express an opinion on the main } \\
\text { problem, show mostly }\end{array}$} \\
\hline $\begin{array}{l}\text { B1.1- } 10 \\
\text { grade } \\
\text { B1.2-11 } \\
\text { grade }\end{array}$ & $\begin{array}{l}\text { B1.2-11 grade } \\
\text { C1.1- } 12 \text { grade }\end{array}$ & \\
\hline
\end{tabular}




\begin{tabular}{|c|l|l|}
\hline \multicolumn{1}{|l|}{} & & $\begin{array}{l}\text { advantages and drawbacks of } \\
\text { different opinions. }\end{array}$ \\
\hline 11- year school & 12 -year school & Expected outputs \\
\hline Tertiary education - C1. & Tertiary school-C1.2 & $\begin{array}{l}\text { Fluent user C1 } \\
\text { Can understand complex texts on } \\
\text { various topics, perceive } \\
\text { concealed meaning. Can speak } \\
\text { spontaneously in a fast pace, } \\
\text { without difficulty with choosing } \\
\text { words and collocations. Use } \\
\text { language flexibly and efficiently } \\
\text { to communicate in scientific and } \\
\text { professional activity. Can make } \\
\text { detailed, precise, well-structured } \\
\text { messages. The son difficult } \\
\text { topics, showing mastering of } \\
\text { models of organizing texts. }\end{array}$ \\
\hline & \multicolumn{2}{|l}{} \\
\hline & &
\end{tabular}

\subsection{Implementation stages of the model}

\subsubsection{Diagnostic stage}

The state of foreign language teaching was investigated in Akmola, Almaty and Pavlodar regions of Kazakhstan. Interviews with specialists of foreign languages and a survey took place; results of school and university students' performance and the quality of training conducted by teachers of different subjects and teachers of foreign languages were studied; information on polylinguism development was provided.

Recommendations on foreign languages teaching evaluation at school were prepared:

1) The level of the subject «Foreign language» training:

A) Compliance of educational process with modern requirements of language learning (knowledge of training strategic goals, tactical steps to implement strategic objectives, normative acts management, analysis of documentation of 2-3 lessons at school, relationship with other linguistic and non-linguistic subjects);

Б) Teachers' knowledge of effective technologies, knowledge of lessons typology, percentage of instructional time for formation and improvement of language, speech and communication competences, and modern methods of assessment;

B) Organization of extracurricular activities on the subject (interrelation of lessons and extracurricular activities, operation of clubs and electives, students' participation in school and town (village) social life on the basis of the Russian language skills);

Г) Achievements of school students on the subject "Foreign Language" (participation in school Olympiads, preparation and defending of research projects, publication of students' works in the media and collections of scientific conferences);

Д) Results of scheduled tests on the subject (departments of education), the UNT.

E) Results of test papers performed within the framework of the project. 
2) The level of educational-methodological and technical support of the subject "Foreign language":

A) The availability of a model curriculum at school and approved calendar plan for the subject;

B) The availability of academic literature on the subject according to the list of textbooks approved by the MES for the current academic year;

C) The availability of foreign languages dictionaries at school (explanatory, bilingual, synonyms, antonyms, thematic, etc.).

D) The availability of subject methodological journals in the library;

E) The availability of foreign language classrooms, characteristic of their methodological and technical equipment

2) The level of teaching staff competence:

A) Compliance with the qualification of education department;

B) The average age of foreign language teachers at schools;

B) The level of education, experience and categories of school teachers;

D) Teachers' training (certificates, courses' level - regional, national, international);

D) Other languages mastered by teachers (except foreign languages), the desire to master the state language and another foreign language;

E) ICT mastering.

Control tests were conducted to check the level of speech and linguistic literacy competence according to the Common European Framework of Reference for Languages. Topics of monologue statements were suggested. Additionally, there were selected classes of the fifth (5), sixth (7), eighth (10) and tenth (10) grades of schools in Almaty region. 65 students of the 5th grade, 107 students of the 6th grade, 136 students of the 8th grade, and 131 learners of the 10th grade were covered by control tests (Table 2).

Table 2: The results of test paper summary analysis on the subject "English" at school

\begin{tabular}{|l|l|l|l|l|l|}
\hline Grades & $\begin{array}{l}\text { Total } \\
\text { number } \\
\text { of } \\
\text { students }\end{array}$ & $\begin{array}{l}\% \text { of } \\
\text { performance }\end{array}$ & $\begin{array}{l}\% \text { of } \\
\text { quality }\end{array}$ & $\begin{array}{l}\text { Disclosure of the } \\
\text { content } \\
\text { (volume of the text } \\
\text { and the number of } \\
\text { micro topics })\end{array}$ & $\begin{array}{l}\text { Level of } \\
\text { mastering } \\
\text { English }\end{array}$ \\
\hline 5 & 65 & 100 & 83 & 98 & A1 \\
\hline 6 & 107 & 100 & 72 & 76 & A1/A2 \\
\hline 8 & 136 & 100 & 68 & 94 & A2/B1 \\
\hline 10 & 131 & 100 & 77 & 89 & B1/B2 \\
\hline Total & 438 & 100 & 75 & 89 & \\
\hline
\end{tabular}

The analysis shows that secondary school teaching, in order to achieve a regulatory level, falls behind by the half-level: expected level of all 10th grade students should be B2. (At the same time it should be noted the presence of individual students who reached level $\mathrm{C} 1$ through individual lessons with a tutor).

Having analyzed students' work we found out what aspects of foreign language training should be improved.

Methodical recommendations on the development of foreign speech for foreign language teachers based on the analysis of works are as follows:

1 There is need to rely on modern pedagogical concepts, linguistic and linguodidactic sciences about features of the text, expression of the author's position and formation of a holistic view on the subject matter. Students do not show creative thinking; their works are monotonous, with frequent set of sentences, and they do not reveal ideas. Therefore, the creative potential of students was not realized due to the lack of vocabulary. 
2 Teachers of foreign languages, regardless of students' residence (urban / rural), should master a unified method of writing essays on specific topics according to the typical program, to carry out a systematic work on key aspects of monologue speech formation: lyrics descriptions, narratives and arguments mastering by means of communication (revealing one micro topic), ways of expressing the author's position.

3 Foreign language teachers should be able to integrate language and speech material, and language means should ensure the disclosure of monologue themes.

4 Teachers should master the technology of complex language, speech and communication competences formation.

5 Educational process needs to be improved in terms of training and methodological support through prepared and dosed educational materials, effective means of training satisfying the volume of academic load at college and in the context of training at higher educational institutions.

6 Insufficiently developed system of tasks for independent work. The quality review technique requires tracking of learning outcomes. Practice-oriented and research activities of students are not provided.

Thus, students with insufficient foreign language training enter universities. In this regard, the Doctor of pedagogical sciences K.N. Bulatbaeva and G.N. Zhamanaeva (2015) published the article on the continuity of the subject "Foreign Language" content at the stages of high school - university.

\subsubsection{Stage of Formation}

To control the efficiency of linguistic subjects' content distribution at schools, we supervised the research into designing syllabuses and textbooks for 12th grades. Research-scientific workshop was held for the authors of textbooks to show principles of parallel presentation of themes. The following textbooks were designed: "Russian language" for the 12th grades of 12-year schools with the Kazakh language of studying by K.N. Bulatbayeva et al. (2014); English for students of the 12th grades of 12-year schools by G.D.Khairullina and R.G.Shaikhutdinov (2014). United thematic base of the following subjects 'Kazakh language (L2)', 'Russian language (L2)', 'English language (L2)' is presented. Each one consists of 10 modules: Historical sightseeing of your native region; Time for peace and creation; To be like the greatest; Human and their possibilities; Human in the modern world: safety rules; Economic competitiveness of our country; Social guarantees - prosperity of our country; Good professional qualities - calls of the times; Innovations in the world; How to develop leadership?

In the frameworks of each module the following work is supposed:

Module: Historical sightseeing of your native region - 7 hours

Educational component: formation of learners`abilities to present historical sightseeing of their native region using the Kazakh\Russian\English languages; increasing the sense of pride for their native region.

Component on speech development: mastering the structure of monologue utterance as a complex of micro-themes: 'place of birth of a prominent person', 'place of a historical event', 'cultural monuments', 'memoirs about native region', 'attitude to native region', 'famous people about native region'.

Practice -4 hours

Improvement of vocabulary skills through listening and reading (1 hour). Repeating peculiarities of colloquial and artistic styles on the base of reading texts (on the theme of the module). Enriching vocabulary on the theme, activation of new lexicalphraseological units in the framework of the given micro-themes. Working with dictionaries: explanatory, dictionary of synonyms, antonyms and epithets. Oral work to improve spelling skills. 
Improvement of grammar skills in speaking through listening and writing (1 hour). Activation of grammar through various grammar structures: successive extension (introduction of subordinate parts of the sentences), expansion (introduction of homogeneous parts of the sentences, requests, specifying parts of the sentences) and complication (usage of predicate clauses, coordinate and subordinate conjunctions). Corrective work to improve punctuation.

Improvement of skills in dialogue communication through reading, listening and speaking ( 1 hour). Making up dialogues in the frameworks of speech theme according to given situations on the base of already read texts. Types of situations: A) interlocutor is familiar, older than another interlocutor, style of communication informal; B) interlocutor is familiar, older than interlocutor's partner, the communication style is formal.

Improvement of monologue speech through speaking and writing (1 hour). Repeating linguistic peculiarities of functional-semantic types of monologue text: description, narration, argument (comparative analysis). Analysis of contexture and linguistic means in text fragments - description, narration and argument. Means of linking sentences in the text: conjunctions, pronouns, synonyms, aspectual-temporal plan of the text, thematic group of words. Stylistic characteristics of the text.

Change of style and grammatical structure of each sentence -1 hour. Transformation of the text.

Oral and written monologue statements -2 hours.

The experiment with textbooks "Kazakh language (L2)", "Russian language (L2)", "English language (L2)" gave positive results. Students demonstrated a sufficient level of language proficiency. Conversations with students of the 12th Grade have revealed that it is much easier to communicate using one topic at different language lessons. Attention is focused on designing the ideas by means of the given language; the content in general is the same, but national peculiarities of culture and specific facts of history of people - natural bearers of a particular language shall be taken into account. Graduates of the 12th experimental grades passed their exams having 1-2 points higher in average than graduates of the traditional 11-year school. Special workshops held for teachers of experimental schools who used the system of criteriabased assessment also gave favorable results.

Mechanism for consecutive selection of teaching material developed by K.N. Bulatbayeva (2005), a number of articles, programs, tutorials and textbooks performed at the time of the research project in 2012-2014, "Scientific and methodological support of multilingual education in secondary and higher education system" (National Academy of Education named after Y.Altynsarin) were used to select professionally oriented teaching material. (Figure 3)

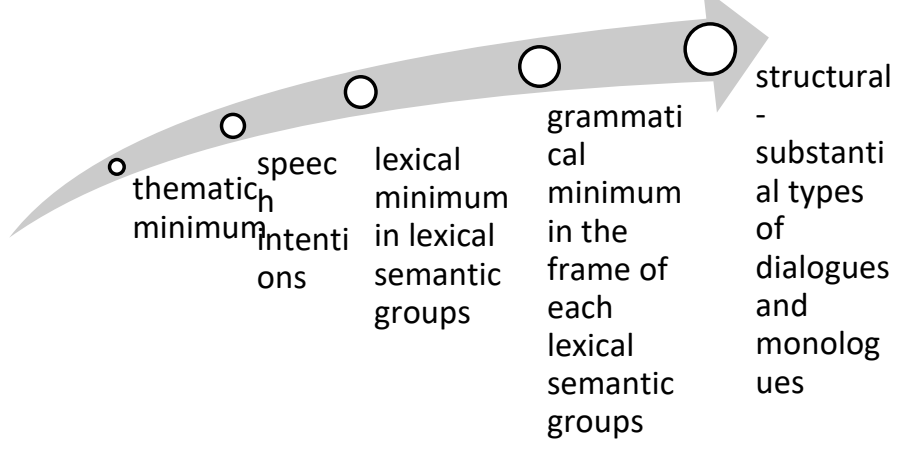


Figure 3: The mechanism of functional teaching material selection for the discipline «Professionally oriented foreign language» (according to Bulatbayeva, 2015)

We selected functional grammatical material for students of the specialty "Oil and Gas Studies ". First of all, a universal textbook which includes key topics of professionally-oriented communication should become the starting point. Such textbook provides the initial base for mastering a professionally oriented foreign language. In our case, it is the textbook "Fundamentals of Oil and Gas Studies " by A.A. Korshak and A.M. Shammazov (2005).

Firstly, we defined the main modules (thematic blocks) for 10 credits and 3 semesters. Secondly, we selected the thematic minimum for 11 thematic blocks, which include 48 themes. The next step was to detect a communicative purpose and the minimum of speech intentions. Then selection of lexical minimum was done. According to the list of 21 semantic types of elementary propositions, described by K.N. Bulatbayeva (2005), we selected 5 active types within each theme and other functional grammatical means on the theme and grammatical minimum. Finally, we distributed selected grammar material according to stages of teaching. (Table3). Final results of teaching a foreign language were structural- substantial types of dialogue and monologue.

Table 3: Correlation of functional language means to stages of teaching a foreign language communicative competence.

\begin{tabular}{|l|l|l|}
\hline № & Stage of teaching & Means of teaching \\
\hline 1 & $\begin{array}{l}\text { Enrichment of topical } \\
\text { vocabulary in a foreign } \\
\text { language }\end{array}$ & $\begin{array}{l}\text { Functional-semantic fields, syntaxemes and } \\
\text { extended syntaxemes within functional- } \\
\text { semantic fields }\end{array}$ \\
\hline 2 & $\begin{array}{l}\text { Enrichment of the } \\
\text { grammatical structure of } \\
\text { speech in a foreign language }\end{array}$ & $\begin{array}{l}\text { Semantic types of elementary propositions, } \\
\text { speech acts syntaxemes and extended } \\
\text { syntaxemes within semantic types of } \\
\text { elementary propositions }\end{array}$ \\
\hline 3 & $\begin{array}{l}\text { Development of dialogue and } \\
\text { poly-logue professional } \\
\text { communication skills }\end{array}$ & $\begin{array}{l}\text { Speech acts, idiomatic structures of } \\
\text { communication, structural- substantial } \\
\text { types of dialogue, communicative speech } \\
\text { registers }\end{array}$ \\
\hline 4 & $\begin{array}{l}\text { Development of } \\
\text { professionally } \\
\text { monologue speech oriented }\end{array}$ & $\begin{array}{l}\text { Structural-substantial types of monologue, } \\
\text { communicative speech registers }\end{array}$ \\
\hline
\end{tabular}

\subsubsection{Final control}

Final control: the production of oral or written monologue statements in the $12^{\text {th }}$ experimental grades.

Sample topics for the oral statement: "The leader of my generation", "Leadership skill", "Can anyone be a leader".

Sample topics for written statements are: "Whose example I follow", "The harmony of the inner world and intellectual achievements".

Parameters of oral statement assessment:

1) Information value -50 points

a) the size of the text (the number of words ) (0-10);

b) the number of micro-topics (content items) (0-15);

c) the ability to get in contact with the interlocutor, the variety of communicative speech registers $(0-10)$; 
g) consistency (coherence of parts, completeness) (0-15).

2) Linguistic correctness in the area- 50 points:

a) lexis (0-15);

b) grammar (morphology, syntax) (0-20);

c) compliance with orthoepy rules (0-5);

g) fluency (0-10).

Parameters of written statement assessment:

1) Information value - 50 points

a) the size of the text (the number of words) (0-10);

b) the number of micro-topics (content items) (0-15);

c) the ability to get in contact with the interlocutor, the variety of communicative speech registers $(0-10)$;

g) consistency (coherence of parts, completeness) (0-15).

2) Linguistic correctness in the area- 50 points:

a) lexis (0-25);

b) grammar (morphology, syntax) (0-25).

Table 4: Criteria to assess the level of oral and written monologue speech in school leavers

\begin{tabular}{|c|c|c|}
\hline Grade & 12 & \\
\hline Criteria & Oral speech & Written speech \\
\hline $\begin{array}{l}1 \text { Volume of text } \\
0-10 \text { points }\end{array}$ & $\begin{array}{l}50 \text { words }- \text { («excellent») } \\
40-49 \text { words }- \text { «good» } \\
30-39 \text { words } \\
\text { «satisfactory» } \\
\text { Less than 30 words - } \\
\text { «unsatisfactory» }\end{array}$ & $\begin{array}{l}230-250 \text { words }-(\text { («excellent») } \\
200-\text { - } 230 \text { words }- \text { «good» } \\
140-\text {-д } 200 \text { words } \\
\text { «satisfactory» } \\
\text { Less than } 140 \text { words }- \\
\text { «unsatisfactory» }\end{array}$ \\
\hline $\begin{array}{l}2 \quad \text { Number } \\
\text { microthemes } \\
0-15 \text { points }\end{array}$ & $\begin{array}{l}5-(\text {-excellent») } \\
4-\langle\text { good» } \\
3-\text { - «satisfactory» } \\
2-\text { - unsatisfactory» } \\
\end{array}$ & $\begin{array}{l}7-(\text { «excellent») }) \\
5-6-\langle\text { good» } \\
4-\text { «unsatisfactory» } \\
3-\text { «unsatisfactory» } \\
\end{array}$ \\
\hline $\begin{array}{l}3 \text { Ability to } \\
\text { communicate with } \\
\text { a partner, } \\
\text { diversity of } \\
\text { communicative } \\
\text { speech registers } \\
\text { in oral and written } \\
\text { speech }\end{array}$ & \multicolumn{2}{|c|}{$\begin{array}{l}\text { High level: application of a dialogue method for texts of } \\
\text { different styles; free handling of contact-establishing devices; } \\
\text { interchange of different communicative speech registers - } \\
\text { 'excellent'. } \\
\text { Good level: correct use of contact-establishing devices } \\
\text { without any methods of address, modest variety of } \\
\text { communicative registers of speech, using of wide-spread } \\
\text { methods of speech intensions - 'good'. } \\
\text { Competent level: } 1-2-3 \text { contact-establishing devices of } \\
\text { different levels without special intention to addressee - } \\
\text { 'satisfactory.' } \\
\text { Low level: adressless monologue, } 1-2 \text { communicative speech } \\
\text { registers (mainly, reproductive and informative) - } \\
\text { 'unsatisfactory. }\end{array}$} \\
\hline $\begin{array}{l}4 \text { Consistence of } \\
\text { oral and written } \\
\text { speech } \\
0-15 \text { points }\end{array}$ & \multicolumn{2}{|c|}{$\begin{array}{l}\text { Thematic unity of the text - 'excellent'. Linear-unfolded } \\
\text { connection - 'good'. Parallel connection - 'satisfactory'. } \\
\text { Successive connection - 'unsatisfactory'. }\end{array}$} \\
\hline $\begin{array}{l}5 \\
\text { correctness of oral } \\
\text { and } \\
\text { speech }\end{array}$ & \multicolumn{2}{|c|}{$\begin{array}{l}\text { For each lexical, morphological, syntactical mistake } 0,25 \text { of } \\
\text { point is decreased ( } 0-35 \text { of points in oral speech; } 0-50 \text { points } \\
\text { in written speech). } \\
\text { Observing orphoepic norms in oral speech ( } 0-5 \text { points in oral }\end{array}$} \\
\hline
\end{tabular}




\begin{tabular}{|l|l|}
\hline 50 points & $\begin{array}{l}\text { speech) (Pronunciation without mistakes - «excellent». } \\
\text { Minor mistakes - «satisfactory». Speech is not clear- } \\
\text { «unsatisfactory»). }\end{array}$ \\
$\begin{array}{l}\text { Fluency in oral speech (0-10 points) } \\
\text { (fluent and natural speech - «excellent». 1-3 intervals - } \\
\text { «good». 4-6 intervals - «satisfactory». More than 6 intervals } \\
- \text { «unsatisfactory»). }\end{array}$ \\
\hline
\end{tabular}

7. Final test - word quiz with a grammar task

Specifications of word quiz assessment with a grammar task (0-100 points):

Spelling accuracy (0- 25 points);

Punctuation (0-25 points);

Morphological analysis of the word (0-25 points);

Syntactical analysis of the sentence (0-25 points).

The 100-grade system of intermediate and final assessment was adopted in the 12th experimental grades in 2014-2015; in accordance with it, the method of assessment of any linguistic subject was performed. We controlled the level of linguistic, speech and communicative competences in Russian as a second language and English in Kazakh schools.

58 students of the 12th grade from Kazakh schools took part in writing final essays on the given topics. As a result of controlling the level of monologue utterance in the Russian language as a second language and the English language, learners showed an average level (75\% in Russian and 78\% in English) and a high level (21\% in Russian and $9 \%$ in English) of knowledge.

Selection of lexical and grammatical material for the specialty "Oil and Gas Studies" was accomplished; a series of lessons was developed and tested in laboratory conditions during the educational process. The experiment involved students of the group "Oil and gas studies -102" at Pavlodar State University named after S. Toraigyrov; they were divided into 2 groups. In the first group (experimental - EG), students learned the theme "Energy Sources" on the basis of selected educational material given stage-by-stage, and the second - control group (CG) - worked according to traditional methods: attention is paid to grammar and work with randomly selected text. Having compared the course of the experiment in these two groups, several differences were determined: students of the EG showed a natural interest in the theme about their future profession, they learned to form their thoughts grammatically correctly according to the theme and participated in the discussion. The students were excited to become absorbed into the topic related to their future professional activity instead of learning common things ("My apartment", "My hobby", "My family") which are unlikely to be useful in their future professional communication.

Students made up dialogues and monologues for further assessment. The results of dialogue and monologues assessment are the following (Table 5):

Table 5: Results of dialogue and monologue assessment

\begin{tabular}{|l|l|l|l|l|l|l|l|l|}
\hline \multicolumn{2}{|l|}{ Dialogues } \\
\hline
\end{tabular}

XLinguae, Volume 11, Issue 2, April 2018, ISSN 1337-8384, eISSN 2453-711X 


\begin{tabular}{|c|c|c|c|c|c|c|c|c|}
\hline $\begin{array}{l}\text { e for } \\
\text { CG }\end{array}$ & 7 & & & & & & & 4 \\
\hline $\begin{array}{l}\text { averag } \\
\mathrm{e} \quad \text { for } \\
\mathrm{EG}\end{array}$ & $\begin{array}{l}13,3 \\
3\end{array}$ & 3,51 & 3,96 & 4,27 & 4,61 & 3,98 & 4,03 & $\begin{array}{l}24,3 \\
6\end{array}$ \\
\hline \multicolumn{9}{|c|}{ Monologues } \\
\hline & $\begin{array}{l}\text { Total } \\
\text { amount } \\
\text { of } \\
\text { words }\end{array}$ & $\begin{array}{l}\text { Total } \\
\text { amount } \\
\text { of } \\
\text { micro- } \\
\text { themes }\end{array}$ & $\begin{array}{l}\text { Points } \\
\text { for } \\
\text { amount } \\
\text { of } \\
\text { words } \\
(0-5 \\
\text { points })\end{array}$ & $\begin{array}{l}\text { Points for } \\
\text { the } \\
\text { number } \\
\text { of micro- } \\
\text { themes } \\
\text { ( } 0-5 \\
\text { points) }\end{array}$ & \multicolumn{2}{|c|}{$\begin{array}{l}\text { ability to } \\
\text { establish } \\
\text { contact with a } \\
\text { person, a } \\
\text { variety of } \\
\text { communicatio } \\
\text { n registers (0- } \\
5 \text { points) }\end{array}$} & $\begin{array}{l}\text { grammati } \\
\text { cal } \\
\text { correctne } \\
\text { ss } \quad(0-5 \\
\text { points })\end{array}$ & $\begin{array}{l}\text { Total } \\
\text { amo } \\
\text { unt } \\
\text { of } \\
\text { point } \\
\text { s } \\
(0-20 \\
\text { point } \\
\text { s) }\end{array}$ \\
\hline $\begin{array}{l}\text { averag } \\
\mathrm{e} \quad \text { for } \\
\mathrm{CG}\end{array}$ & 124,67 & 4,58 & 3,17 & 2,67 & \multicolumn{2}{|l|}{3,42} & 4,06 & $\begin{array}{l}13,3 \\
1\end{array}$ \\
\hline $\begin{array}{l}\text { averag } \\
\mathrm{e} \quad \text { for } \\
\mathrm{EG}\end{array}$ & 170,11 & 8,01 & 4,01 & 4,09 & \multicolumn{2}{|l|}{4,35} & 4,54 & $\begin{array}{l}16,9 \\
9\end{array}$ \\
\hline
\end{tabular}

The average number of words in the experimental group's monologues is by $25-28 \%$ more. Their monologues have more micro- themes (approximately 2 times more). We think that the main result is that students of EG got higher scores in grammar assessment. They tried to express their thoughts using different ways. They punctuated correctly and used different ways of extending, complication, complexification of grammar structures in sentences.

So as to form communicative competence in several languages, we have gradually changed the meaningful education system in the following aspects:

1) expected results of learning on the basis of modern educational model standards have been clearly defined;

2) we have predicted steps of knowledge, skills, application, analysis, synthesis and creativity in expected results;

3) a hierarchical system of subject content based on strategies and tactical steps of learning have been identified, i.e. one dominant line and components "working" for this dominant line have been revealed;

4) the typology of lessons in accordance with the hierarchical system of the subject content has been derived;

5) for each type of current lessons we have developed assessment criteria depending on specific learning objectives;

6) specific criteria have been worked out for a generalizing lesson type (designed to combine all knowledge and skills in a particular competence).

All these aspects are reflected in developed technologies. Moreover, uniform criteria have been elaborated to assess linguistic, speech and communicative competences of school and university students (Bulatbayeva, 2011, 2015).

\section{Conclusion}

The study conducted over the period of 2012-2017 enabled to draw the following conclusions:

Results of communicative competence achievements in students studying the second and third languages have become possible due to educational process optimization and new cognitive-communicative approach when the selection of educational material content is based on real needs of communication. Minimization of communication spheres, topics of communication and situations of communication allowed to arrange the content of educational programs in a new way. In this regard, 
at the level of school education, students showed the ability to communicate fluently in a foreign language, to produce their own texts as both lexical and grammar material was presented systematically on a semantic basis; then students trained in dialogue communication and oral monologue public speaking. University students ("Oil and gas studies" specialty) showed high results as well.

Testing of designed textbooks for the $12^{\text {th }}$ grade in the Russian (second) language and English (third) language in experimental schools had positive results. The anthropocentric approach was actually implemented in practice when students discussed the same topic within the same period of time in two languages; they drew a parallel between countries considering the same topics; increased motivation to master languages was noticed as the process of live communication concerning real life problems was employed. At the same time, the language system was assigned the role to serve the communication process. Students noted that it was much more interesting to use these textbooks.

Teachers of Russian and English languages in Kazakh school were trained at seminars the ways of teaching according to new textbooks. They learned to model potential situations of communication within the theme, to take into account the strategy and tactical steps of planning different types of lessons in a certain sequence. Students passed their final exams much better than those who studied languages according traditional methods of training.

Positive results were obtained on the discipline "Professional foreign language" in the first year of studying in the specialty "Oil and gas studies" when students of the experimental group could start professional communication within a short period of time, while students of control groups could only mechanically reproduce sentences from the text they remembered, and they did not communicate fluently.

A month after the material had been studied, the final test was conducted: students of the experimental group could just the same fluently communicate on the covered topic. As for students of control groups they forgot earlier studied material since their training was not based on motivated speech tasks. The conclusion was as follows: only "artificial immersion in a natural situation" gives effective mastering of a foreign language as a language of future specialty; students of experimental groups remembered the material better because they played different roles: an observer, a participant of the event, an information owner, an adviser, a supervisor, a subject etc.

Thus, updated content of language training at school and university requires new linguistic-didactic approaches to teaching based on potential communicative needs of students and implemented through application of the latest scientific achievements.

\section{Acknowledgements}

The work is performed according to the Russian Government Program of Competitive Growth of Kazan Federal University.

The paper was supported by grants from the Ministry of Education and Science of the Republic of Kazakhstan "Scientific-methodical maintenance of multilingual education in secondary and high school" (2012-2014), and "Scientific basis of continuous linguodidactic education for specialists of foreign languages in Kazakhstan" (20152017).

\section{Bibliographic references}

BULATBAYEVA, K.N. - SYZDYKOVA, G.S. - SHAIMARDANOVA, K.V. SHAKHMETOVA, N.A. 2014. Russian language. Almaty: Exclusive. ISBN 978601-7228-06-4

BULATBAYEVA, K.N. - ZHAMANAEVA, G.N. 2015. Continuity of the functional content of education in the model "high school - University". In: Journal recommended by the Committee of Science, vol 2, pp. 452-464. ISSN 1999-4214

XLinguae, Volume 11, Issue 2, April 2018, ISSN 1337-8384, eISSN 2453-711X 
BULATBAYEVA, K.N. 2005. Functional-communicative technology of teaching Russian language in Kazakh schools. Pavlodar: SIC PSU. ISBN 9965-439-11-7

BULATBAYEVA, K.N. 2011. Cognitive-communicative technology as a condition for the development of mass polylinguism in educational institutions of Kazakhstan. In: materials of International Scientific Conference "Changes in the education: new boundaries and priorities". Almaty: APN of Kazakhstan. ISBN 978-601-278-531-9

BULATBAYEVA, K.N., 2015. Common criteria for evaluating language, speech and communicative competences in teaching languages at school and University. Cheboksary: TSNS "Interaktiv plus". ISBN 978-5-906626-42-4

COUNCIL OF EUROPE. 2001. Common European framework of reference for languages: learning, teaching, assessment. Cambridge: Press Syndicate of the University of Cambridge.

FAHRUTDINOVA, G.ZH. 2016. Ethno-Pedagogical Factor of Polycultural Training. In: International Journal of Environmental \& Science Education, vol. 11, n.6, pp. 1185-1193. ISSN: 13063065.

FORMANOVSKAYA, N.I. 1989. Speech etiquette and culture of communication. Moscow: Vysshaya Shkola. ISBN 5-06-000181-4

KARAULOV, YU.N. 1976. Obshchaya i russkaya ideografiya. Moscow: Nauka. ISBN: 978-5-397-01238-6

KARAULOV, YU.N. 2010. Russkii jazyk i yazykovaia lichnost. Moscow: LKI Publishers. ISBN: 978-5-382-01071-7

KHAIRULLINA, G.D. - SHAIHUTDINOV, R.G. 2014. Specimen for students of the 12th grades of 12-year schools. Almaty: Publishing house «Exclusive». ISBN 978-601-7228-08-8

KORSHAK, A.A. - SHAMMAZOV, A.M. 2001. Basic Principles of Oil and Gas Engineering. Ufa: Design Polygraph Service. ISBN 5-94423-002-9.

LI, N. - PYRKOVA, K.V. - RYABOVA, T.V. 2017. Teaching Communication Skills and Decision-Making to University Students. In: EURASIA Journal of Mathematics, Science and Technology Education, vol. 13, n. 8, pp. 4715-4723. ISSN: 13058215, 13058223.

PASSOV, E.I. 1989. Fundamentals of foreign language communicative teaching methodology. Moscow: Russian language. ISBN 5-200-00717-8.

ROGET, P. M. 1978. Roget's thesaurus of English words and phrases. London: Penguin Books. ISBN 0140510079,

STATE PROGRAM OF LANGUAGE DEVELOPMENT AND FUNCTIONING IN THE REPUBLIC OF KAZAKHSTAN IN 2011-2020. 2011. Approved by the Decree of the President of the Republic of Kazakhstan dated of June 29, 2011 No. 110, Astana. Available online: http://www.akorda.kz/en/official_documents/strategies_and_programs

WANG, S. - GORBUNOVA, N.V. - MASALIMOVA, A.R. - BIROVA, J. SERGEEVA, M.G. 2018. Formation of Academic Mobility of Future Foreign Language Teachers by Means of Media Education Technologies. EURASIA Journal of Mathematics, Science and Technology Education, vol. 14, n. 3, pp. 959-976. ISSN: $13058215,13058223$.

ZOLOTOVA, G.A. - ONIPENKO, N.K. - SIDOROVA, M.YU. 2004. Communicative Grammar of the Russian language. Moscow: Editorial URSS, ISBN 5-88744-050-3.

Words: 6671

Characters: 46317 (25.73 standard pages)

Prof. Guzalyia Zh. Fahrutdinova, Dr.

Institute of Psychology and Education

Kazan (Volga region) Federal University 
18 Kremlyovskaya Str.

420008 Kazan

Russia

gdautova@mail.ru

Prof. Kulzhanat N. Bulatbayeva, Dr.

Department of Foreign Philology

L.N. Gumilyov Eurasian National University,

2 Satpaev Str.

010008 Astana

Kazakhstan

bulatbaeva.kulzhanat@mail.ru

Olga I. Kondratova,

of the Department of Foreign Philology,

L.N. Gumilyov Eurasian National University,

2 Satpaev Str.

010008 Astana

Kazakhstan

olya_1994_30@mail.ru

Prof. Svetlana N. Fedorova, Dr.

Faculty of Education and Psychology,

Mari State University,

44 Kremlyovskaya Str.

424002 Yoshkar-Ola

Russia

svetfed65@rambler.ru

Assoc. Prof. Olga A. Petukhova, PhD

Faculty of Education and Psychology,

Mari State University,

44 Kremlyovskaya Str.

424002 Yoshkar-Ola

Russia

art-ga@mail.ru 